\title{
MENGKRITISI RUU KERUKUNAN UMAT BERAGAMA: MENJAMIN ATAU MEMBATASI KEBEBASAN?
}

\author{
Setyo Pamungkas \\ Pegawai Negeri Sipil pada Dinas Ketenagakerjaan, Sosial dan Transmigrasi \\ Pemerintah Kota Salatiga \\ Korespondensi: setyopamungkas@gmail.com
}

\begin{abstract}
Abstrak
Pengakuan terhadap kebebasan untuk beragama dan berkeyakinan merupakan sebuah penegasan terhadap prinsip bahwa kebebasan beragama dan berkeyakinan adalah hak dasar.Kebebasan beragama dan berkeyakinan tersebut saat ini terancam dengan adanya keinginan untuk membentuk undang-undang, yaitu Rancangan Undang-Undang tentang Kerukunan Umat Beragama. Permasalahan dari RUU tersebut adalah apakah dengan pengaturan hal itu mendorong masyarakat untuk toleran atau justru menjadi alat untuk mengintervensi keberadaan umat beragama di Indonesia. RUU KUB bisa saja melegalisasikan kehidupan beragama yang nyaman, namun juga melegalisasikan usahausaha untuk membatasi ruang gerak penyebaran agama melalui eksistensi umat, khususnya kaum minoritas sehingga hal itu tidak konsisten dengan semangat kemajemukan.
\end{abstract}

Kata-kata Kunci: Kebebasan Beragama; Toleransi; Pengaturan.

\begin{abstract}
Recognition of the freedom of religion and belief is an affirmation of the principle that freedom of religion and belief is a basic rights. This basic freedom is currently threatened by the aspiration to establish a law, as reflected by intense discussion of the Bill on Religious Harmony. The problems of the bill is whether the law will encourage people to be tolerant, or just become a tool to intervene in the existence of religious communities in Indonesia. The Bill on Religious Harmony could establish contented religious life, but it could also formalize efforts to limit the spreading of religions which is in turn not consistent with the spirit of pluralism.
\end{abstract}

Key Words: Religious Freedom; Tolerance; Pluralism. 


\section{PENDAHULUAN}

Pengakuan terhadap kebebasan untuk beragama dan berkeyakinan merupakan sebuah penegasan terhadap prinsip bahwa kebebasan beragama dan berkeyakinan adalah hak dasar. Pada perkembangan hak asasi manusia di dunia, dalam berbagai konvensi internasional hak asasi manusia, memeluk agama atau memeluk keyakinan tertentu adalah nonderogable rights. Hal ini dikarenakan bahwa hak tersebut tidak dapat dikurangi serta melekat pada diri manusia. Hak asasi untuk beragama menjadi hak yang mutlak, tidak dapat diganggu gugat oleh pihak manapun dan layak untuk dilindungi.

Bangsa Indonesia di dalam perkembangan sejarah kebebasannya, mampu membuktikan untuk hidup dalam kedamaian, di mana perbedaan agama tidak memberikan dampak signifikan terhadap munculnya konflikkonflik horizontal. Sejalan dengan itu, prinsip Bhineka Tunggal Ika menjadi elemen penting yang mendasari sikapsikap saling asah, asih dan asuh. Keanekaragaman mendidik bangsa
Indonesia untuk saling memberikan toleransi dan memperhatikan satu sama lain.

\section{PEMBAHASAN}

\section{Pengakuan dalam Instrumen Hukum}

Sejarah pengakuan hak kebebasan beragama adalah sesuatu yang unik, karena kebebasan beragama senantiasa berhadapan dengan multi-kepentingan, baik terkait dengan pemaknaan kebebasan beragama itu sendiri, maupun politisasi di bidang agama dan keyakinan. Artikel 18 the Universal Declaration of Human Rights dan Artikel 18 the International Covenant on Civil and Political Rights menuangkan adanya pengakuan bahwa "freedom of thought, conscience, religion and belief as a nonderogable human right". ${ }^{1}$

Melalui konstitusinya pula, Indonesia memberikan jaminan bahwa warga negara Indonesia memilik hak untuk memeluk agama dan beribadah menurut agama dan kepercayaannya itu. Jaminan tersebut tegas termuat dalam Pasal 29 ayat (2) Undang-Undang Dasar Negara Republik Indonesia Tahun

\footnotetext{
Di komunitas negara-negara Eropa, dimuat dalam Article 10 the European Charter of Fundamental Rights yang menyatakan bahwa: "Everyone has the right to freedom of thought, conscience and religion. This right includes freedom to change religion or belief and freedom, either alone or in community with others and in public or in private, to manifest religion or belief, in worship, teaching, practice and observance." Bahwa pengakuan ini dan konvensi lainnya di dunia, selain mengacu pada the Universal Declaration of Human Rights, juga the Helsinki Final Act. Misalnya Artikel 12 the American Convention on Human Rights of the Organization of American States dan Artikel 8 the African Charter on Human and People's Rights from the African Union. Dengan demikian, komunitas global menyadari bahwa setiap individu di dunia ini memiliki kebebasan untuk beragama atau tidak beragama, berkeyakinan atau tidak berkeyakinan, serta menjalankan atau tidak ibadah menurut agama atau keyakinannya yang pelaksanaannya harus bebas dari pembatasan (individuals have unlimited freedom to believe or not to believe, to change religion, as well as the freedom to worship, either alone or in community with others, subject to only the narrowest of limitations). Lihat: Knox Thames, Making Freedom of Religion or Belief a True EU Priority. EUI Working Papers, RSCAS 2012/41.
} 
1945 (UUD NRI 1945) yang berbunyi: "Negara menjamin kemerdekaan tiaptiap penduduk untuk memeluk agamanya masing-masing dan untuk beribadat menurut agamanya dan kepercayaannya itu". Muatan kebebasan beragama dan berkeyakinan ini menjadi satu-satunya hak asasi manusia yang tegas dan diatur di dalam UUD NRI 1945, yang berbeda dengan keberadaan hak asasi yang lainnya. Pernyataan jaminan di dalam pasal tersebut, mengindikasikan bahwa negara memiliki kepentingan yang wajib untuk dilakukan dalam rangka memberikan perlindungan. Pemaknaan terhadap pengaturan kebebasan beragama di Indonesia, memberikan dampak yuridis bagi munculnya peraturan perundangundangan.

Pertanyaan yang wajib diajukan, mengenai implementasi dari ketentuan dalam konstitusi tersebut, setidaktidaknya ada dua hal. Pertama, bagaimana negara sebagai pelindung, memberikan jaminan kepada warga negaranya untuk beragama (atau berkeyakinan) dan mengembangkan ibadahnya. Artinya negara sebagai subyek yang memiliki kuasa dan kewenangan mengatur, memberikan ruang yang sekaligus juga menyediakan kenyamanan berlindung bagi hak bebas beragama serta kegiatan beribadahnya. Kedua, bagaimana kemudian negara dalam rangka memberikan jaminan untuk bebas beragama, mampu menjadi pihak yang memberikan pedoman atau koridor pelaksanaan kegiatan beragama dan berkeyakinan sebagaimana diatur dalam Pasal 29 ayat (2) UUD NRI 1945, tanpa menciderai makna kebebasan beragama itu sendiri.

Penetapan Presiden No. 1 Tahun 1965 yang kemudian ditetapkan menjadi Undang-Undang No. 1/PNPS/ 1965 tentang Pencegahan Penyalahgunaan dan/atau Penodaan Agama Terhadap Kehidupan Beragama di Indonesia dianggap sebagai solusi agar pelaksanaan kehidupan beragama di Indonesia dapat terlindungi dengan baik dan tidak terganggu dengan adanya tindakan-tindakan yang menciderai ajaran moral itu.

Sedangkan, di sisi lain ada masyarakat yang bermaksud bahwa undang-undang dikritisi dalam soal fungsi dan isinya karena multitafsir dan cenderung multi tafsir dan dikhawatirkan akan terjadi intervensi negara yang terlalu jauh terhadap kehidupan beragama. Apabila terjadi hal-hal yang dikategorikan atau yang dianggap penodaan atau penyimpangan, maka itu hendaknya disikapi atau diselesaikan dengan pembinaan internal tanpa kekerasan, tanpa intimidasi dan tindakan fisik. ${ }^{2} \mathrm{Hal}$ ini menjadi masalah, negara ternyata belum memiliki kemampuan yang sebanding dengan ide-ide untuk upaya perlindungannya. Masih berada pada tataran metafisis. Alasan-alasan yang dikemukakan juga harus diakui sebagai fenomena yang unik. 
Hal utama yang penting diingat adalah Pancasila dan Undang-Undang Dasar RI 1945 menjadi landasan negara untuk menjamin setiap warga negara Indonesia, untuk benar-benar bebas memeluk agama dan beribadah sesuai agama dan kepercayaan yang dianutnya. Pemerintah memiliki kewajiban untuk menjalankan amanat dasar negara dan konstitusi tersebut. Akan tetapi, negara dalam kondisi melakukan pembiaran bagi munculnya bentuk kekerasan terhadap kelompok minoritas. Negara bahkan dianggap mengabaikan terjadinya berbagai pelanggaran kebebasan beragama serta indikasi adanya lemahnya penegakan hukum terhadap kebebasan beragama.

\section{RUU Kerukunan Umat Beragama: Mencetak Toleransi Melalui Regulasi}

Perkembangan dewasa ini, agama dan kepercayaan menjadi salah satu isu sentral dalam kehidupan masyarakat di Indonesia. Masyarakat kemudian hidup di bawah rasa ketidak-nyamanan dengan adanya fungsi negara sebagai pelindung kebebasan beragama, tidak berperan secara optimal, cenderung membiarkan adanya kekerasan fisik dan non fisik dalam rangka pengembangan kehidupan yang beragama di Indonesia. Peraturan perundang-undangan yang sudah dibentuk dan upaya penegakkannya, justru menjadi caracara yang intoleran bagi perkembangan kehidupan beragama di Indonesia.

Uji materi Undang-Undang No. 1/ PNPS/1965 yang diajukan pada Mahkamah Konstitusi RI, menjadi salah satu kristalisasi dalam memberikan evaluasi kepada negara, yakni negara belum mampu menjadi subyek yang dibebani tanggung jawab untuk melindungi warga negaranya. UndangUndang No. 1/PNPS/1965 dianggap tidak lagi sesuai dengan perkembangan masyarakat yang semakin kritis di Indonesia, semakin meningkat pengetahuannya dan kehidupan beragama semakin berkembang. Uji materi diajukan dengan beberapa sebab, diantaranya bahwa undang-undang tersebut dianggap sebagian kalangan memberikan peluang bagi negara untuk mengintervensi kehidupan beragama, lemahnya peranan negara dalam memberikan perlindungan, serta isu kekerasan sebagai cara penerapan undang-undang di dalam pelaksanaan kehidupan beragama. Munculnya Surat Keputusan Bersama 3 (tiga) Menteri juga tidak memberikan solusi bagi perlindungan kaum minoritas. Penegakan hukum berbeda dengan persamaan persepsi terhadap jaminan perlindungan.

Pada titik inilah, inisiatif muncul di lembaga perwakilan rakyat. Dewan Perwakilan Rakyat kemudian membentuk ide untuk menerbitkan undang-undang tentang kerukunan umat beragama. Rancangan UndangUndang Kerukunan Umat Beragama dimaksudkan untuk menciptakan kerukunan dan keharmonisan dalam beragama, dengan tetap tidak mengesampingkan adanya kebebasan beragama. Seperti yang tertuang di dalam UDHR bahwa freedom of religion or Freedom of belief is a principle that supports the freedom of an individual or 
community, in public or private, to manifest religion or belief in teaching, practice, worship, and observance; the concept is generally recognized also to include the freedom to change religion or not to follow any religion. ${ }^{3}$

Naskah akademik dan Rancangan Undang-Undang tersebut telah dibuat dan disebarkan kepada masyarakat sebagai bentuk upaya sosialisasi awal tentang mengimplementasi-kan kebebasan beragama yang dilindungi konstitusi. Di dalam naskah akademik RUU Kerukunan Umat Beragama dinyatakan salah satu alasan kenapa rancangan undang-undang ini penting adalah sebenarnya memang telah ada peraturan perundang-undangan yang merupakan pengejawantahan tentang jaminan konstitusi terhadap kebebasan beragama namun justru dianggap bertentangan dengan semangat kebebasan beragama sebagaimana diatur dalam UUD NRI 1945 dan undang-undang lain yang selaras dengan UUD NRI 1945. Inilah kemudian menjadi alasan mengapa peraturan perundang-undangan yang bertentangan itu perlu direvisi atau dibentuk Undang-Undang baru yang dibangun atas semangat Pasal 29 UUD NRI 1945 dan undang-undang yang selaras dengan konstitusi. ${ }^{4}$ Kemajemukan sebagai realitas, kekayaan dan kekuatan bangsa yang merupakan anugrah Tuhan yang patut disyukuri menjadi ancaman yang mengundang kerawanan sosial yang dapat mengganggu kerukunan umat beragama bahkan mengancam persatuan dan kesatuan bangsa. ${ }^{5}$ Bhineka Tunggal Ika yang terpatri dalam pita yang dicengkeram Burung Garuda mulai dipertanyakan dan menjadi alasan munculnya RUU KUB.

Di dalam Undang-Undang Nomor 25 Tahun 2000 tentang Program Pembangunan Nasional (Propenas 20002004) Bab VI Bidang Pembangunan Agama, kebijaksanaan pembangunan bidang agama butir 1, 2, dan 7 berbunyi: "terwujudnya Undang-undang tentang Kerukunan Umat Beragama”, dan dalam Bab III tentang pembangunan hukum disebutkan salah satu indikator kinerjanya adalah "ditetapkannya Undang-undang tentang Kerukunan Umat Beragama (butir 85)". Inilah embrio rancangan undang-undang yang kemudian oleh Kementerian Agama dilakukanlah kajian, seminar, diskusi dan dialog tentang kerukunan umat beragama sampai terbentuk draft Rancangan Undang-Undang Kerukunan Umat Beragama versi 1 Agustus 2011. Draft Rancangan Undang-Undang Kerukunan Umat Beragama (RUU KUB) per tanggal 1 Agustus 2011, terdiri dari 11 bab dengan 55 pasal. Garis besar muatan materi dalam RUU KUB berdasar draft per tanggal 1 Agustus 2011 adalah bentuk penyelenggaraan kerukunan umat beragama, yaitu: perayaan dan peringatan Hari Besar Keagamaan, penyebarluasan agama, dimana di dalamnya mengatur mengenai

Artikel 18 the Universal Declaration of Human Rights.

Naskah Akademik Rancangan Undang-Undang Kebebasan Beragama (versi Agustus 2011), hal. 9. 
soal penyiaran agama dan pendidikan agama, pemakaman jenazah; dan pendirian tempat ibadah. RUU tersebut sudah dibahas oleh DPR RI pada tahun 2011, dan sampai dengan hari ini belum disahkan. Beragam alasan mengemuka, bahkan RUU yang termasuk dalam Program Legislasi Nasional (Prolegnas) 2011 itu belum bisa terwujud menjadi Undang-Undang Kerukunan Umat Beragama hingga memasuki tahun 2013 ini.

Munculnya RUU KUB ini menimbulkan pro dan kontra di dalam masyarakat. Beberapa kalangan berpendapat bahwa adanya RUU KUB ini bilamana disahkan menjadi undangundang, akan menimbulkan gejolak sosial di masyarakat. RUU KUB dianggap belum mampu mengimplementasikan nilai-nilai jaminan terhadap hak kebebasan beragaman sebagaimana tercantum di dalam konstitusi. RUU KUB yang diharapkan mampu memberikan gambaran secara operasional bagaimana kebebasan beragama diberikan perlindungan, justru dianggap membatasi hak serta memutilasi hak asasi yang diakui secara konstitusional. Setidak-tidaknya ada dua hal mendasar yang menjadi bahan kritikan banyak stakeholders dalam RUU KUB. Pemaknaan hak kebebasan mutlak manusia, yakni sebagai non-derogable rights, dan isu pluralisme di Indonesia. Sebagai hak yang mutlak, kebebasan beragama tidak boleh dikurangi atau dipotong karena melekat pada setiap individu. Sedang pluralisme menunjuk pada faktor keberagaman agama dan keyakinan yang diakui oleh negara, yang memberikan peluang intoleran kepada kaum minoritas bilamana konsepsi pluralisme dipahami menggunakan paradigma sempit. Toleransi memang masih menjadi pendekatan liberal yang klasik dan kuat atas tantangan terhadap stabilitas, perdamaian sipil, dan persatuan sosial yang dihadapi masyarakat sebagai akibat dari perbedaan dan perselisihan agama dan pandangan hidup. ${ }^{6}$ Perselisihan agama dan pandangan hidup yang dimaksud dalam RUU KUB ini merupakan perselisihan yang bersumber dari kerawanan sosial dapat terjadi akibat faktor-faktor non agama seperti kesenjangan ekonomi, politik, sosial budaya, dan faktor-faktor agama seperti pendirian rumah ibadah, penyiaran agama, penodaan agama, peringatan hari-hari besar keagamaan, perkawinan antar pemeluk beda agama serta bantuan keagamaan dari pihak asing. ${ }^{7}$ Faktor-faktor yang menyebabkan perselisihan di masyarakat yang menjadi pertimbangan RUU KUB ini masih perlu diperdebatkan. ${ }^{8}$ Adapun RUU KUB mencoba menggunakan pendekatan ini

\footnotetext{
Lihat dalam hal Menimbang RUU KUB.

Kebebasan Beragama atau Berkeyakinan: Seberapa Jauh? Kanisius; Jakarta, 2010. 73.

Lihat dalam draft RUU KUB.

Baca kembali kasus GKI Yasmin yang telah berkekuatan hukum tetap dengan putusan Mahkamah Agung. Kasus GKI Taman Yasmin misalnya, yang memunculkan masalah berkepanjangan. Jemaat Yasmin menolak direlokasi seperti penawaran Wali Kota Bogor, Diani Budiarto. Mereka menyatakan sudah mengatongi izin membangun. Apalagi, putusan Mahkamah Agung (MA) menyatakan izin mendirikan bangunan (IMB) GKI Yasmin adalah sah. Lantaran tidak mendapatkan IMB, nasib jemaat GKI Yasmin terkatung-katung.
} 
sebagai titik awal bagi pengaturan kebebasan beragama di Indonesia.

\section{Pasal 1 butir 2 RUU KUB} mendefinisikan kerukunan umat beragama merupakan suatu kondisi hubungan antar umat beragama yang ditandai oleh adanya suasana harmonis, serasi, damai, akrab, saling menghormati, toleran dan kerjasama dalam kehidupan bermasyarakat baik intern maupun antar umat beragama. Sedangkan yang dianggap sebagai agama disini adalah agama yang dianut penduduk Indonesia,yaitu Islam, Kristen, Hindu dan Budha (Pasal 1 Ayat(1). Bagaimana dengan Konghucu dan penganut kepercayaan lainnya, apakah saudara-saudara penganut agama dan kepercayaan ini tidak juga dilindungi dalam RUU KUB tersebut? Secara realita, sebagian masyarakat Indonesia masih menganut kepercayaan ataupun agama di luar yang disebutkan dalam RUU KUB, dan tidak dapat dikesampingkan demikian saja. Mengingat RUU KUB ini pada akhirnya diharapkan merupakan hukum nasional yang berlaku untuk setiap warga negara Indonesia.

SETARA Institute mengungkapkan ada 5 kontroversi yang perlu menjadi perhatian khusus terkait dengan adanya draft RUU KUB, di antaranya:

1. Rezim Kerukunan versus Kebebasan, RUU KUB meletakkan kerukunan sebagai variabel independen yang mempengaruhi variabel-variabel kebebasan yang dijamin oleh Konstitusi RI. Hal kebebasan beragama ada kontradiksi antara muatan materi dengan judul rancangan undangundang.

2. Memicu Kontroversi Baru: Paradigma yang dikembang-kan dalam RUU KUB secara tegas mengandung semangat pembatasan jaminan-jaminan konstitusional yakni dengan memandang persoalan pelanggaran kebebasan beragama/ berkeyakinan mengakibatkan RUU KUB justru didesain bukan untuk melindungi korban tapi justru untuk melegitimasi kekerasan yang selama ini dilakukan oleh kelompokkelompok tertentu. Hal ini berarti RUU KUB didesain bukan untuk mengatasi persoalan dan memperkuat jaminan kebebasan serta tidak melindungi pihak-pihak yang selama ini menjadi korban.

3. Mengingkari Kemajemukan: RUU KUB didesain untuk mengokohkan hegemoni mayoritas atas minoritas dan mengingkari kemajemukan.

4. Mengatur yang tidak perlu dan unenforceable (tidak bisa ditegakkan): banyak hal yang tidak perlu diatur dan tidak bisa ditegakkan justru dicantumkan menjadi materi muatan RUU. Misalnya mengenai pendidikan agama di sekolah dan mengatur sesuatu yang tidak ada hubungannya dengan jaminan kebebasan beragama/ berkeyakinan.

Pasal 17 dari RUU-KUB tersebut misalnya, menurut Romo Magnis kata "Penyiaran agama" itu tentu akan jadi perdebatan sengit yang luar biasa hingga negara bisa 
mengintervensinya sebab "Penyiaran Agama" dalam konteks Agama Budha, Islam dan Kristiani sendiri adalah hal yang diamanatkan. "Demikian juga halnya pada Ayat (2) pada Pasal 17 dari RUU tersebut, penyiaran agama dibolehkan kepada orang-orang yang belum beragama atau atheis, sementara di Indonesia dalam kenyataannya tidak ada orang yang tidak beragama sesuai dengan keyakinannya masing-masing seperti agama yang dianut oleh saudara-saudara kita di pedalaman Sumba dan Kalimantan.

5. Pelembagaan Diskriminasi: Pendirian rumah ibadah adalah hak yang melekat dalam hak beragama/ berkeyakinan. Tetapi atas nama kerukunan, ketertiban, RUU KUB melembagakan diskriminasi terhadap elemen-elemen warga negara untuk mendirikan rumah ibadah. Konstruksi pasal-pasal soal pengaturan pendirian rumah ibadah (Pasal 23-28) justru menguatkan diskriminasi yang selama ini tercantum dalam Peraturan Bersama Menteri Agama dan Menteri Dalam Negeri (PBM) No. 9/2006, No. 8/2006 tentang Pedoman Pelaksanaan Tugas Kepala Daerah/ Wakil Kepala Daerah dalam Pemeliharaan Kerukunan Umat Beragama, Pemberdayaan Forum Kerukunan Umat Beragama, yang selama ini menjadi acuan pengaturan pendirian rumah ibadah. $^{9}$
Syarat-syarat yang dicantumkan dalam RUU KUB dalam hal pendirian rumah beribadah ini sangatlah memberatkan khususnya bagi kelompok minoritas yaitu diperlukannya persetujuan warga sekitar saat akan mendirikan tempat ibadah. Terlebih lagi dalam Pasal 25 Ayat (3) diatur bahwa dalam pendirian rumah ibadah, kepala daerah harus meminta pendapat organisasi keagamaan dan pemuka agama setempat.

Permasalahan di atas hanya menjadi salah satu pendapat masyarakat yang mengemuka sebagai respon atas dibentuknya RUU KUB dan kemudian dibahas oleh DPR. Materi muatan di dalam RUU KUB membuka peluang adanya perlindungan sekaligus menciptakan hambatan. Perlindungan nampak pada bagaimana ibadah yang merupakan hak warga negara diatur, tapi menghambat penyebaran nilai-nilai agama (pada dasarnya semua agama mengajarkan umatnya untuk menyebarkan nilai yang dimiliki-nya).

Kedua tujuan itu hendak dicapai dengan regulasi, justru makin mendorong adanya permasalahan horizontal dalam tata kehidupan sosial masyarakat. Kebebasan beragama tidak dapat dipisahkan dari kerukunan hidup umat beragama dan begitu pula sebaliknya, sama dengan adanya UUD NRI 1945 yang tidak dapat dipisahkan dari Pancasila. Secara eksplisit di dalam

SETARA Institute, 'RUU KUB Segregatif dan Mengikis Jaminan Konstitusional Warga Negara' <http://www.setara-institute.org/en/content/ruu-kub-segregatif-dan-mengikis-jaminankonstitusional-warga-negara> diakses 12 Maret 2013. 
UUD NRI 1945 khususnya pada Pasal 29, menjamin kebebasan beragama, sedang Pancasila dengan karakternya yang inklusif dan non-diskriminatif mengamanatkan kerukunan beragama. Interaksi dua landasan negara ini menunjukkan bahwa kerukunan tak boleh sedikitpun menghilangkan kebebasan, dan kebebasan tidak boleh mengancam kerukunan. Dengan demikian akan tercipta keseimbangan antara kerukunan yang dinamis dan kebebasan yang bertanggung jawab, kebebasan dimanfaatkan dalam kerukunan dan kerukunan diupayakan dalam kebebasan. ${ }^{10}$

Pluralisme agama dianggap menjadi masalah karena setiap agama yang diakui di negara ini selalu berpendapat bahwa agama itu sendirilah yang paling benar. Pluralisme berubah menjadi isu negatif bagi keberadaan RUU KUB ini. Secara otentik di dalam naskah-naskah kitab suci masing-masing agama, terdapat nilai bahwa kebenaran moral menyangkut dengan kerukunan antar umat, bukan karena stagnasi ajaran. Kerukunan juga merupakan sesuatu yang dinamik, oleh karena kerukunan tersebut secara dinamis senantiasa dikaitkan dengan kebebasan. Sebenarnya kerukunan tidak terutama dihasilkan dari aturan yang bersifat eksternal, yakni melalui peraturan perundang-undangan, namun secara otentik tumbuh dari dalam penghayatan iman masing-masing individu dan melalui dinamika perjumpaan antar umat yang berbeda. Dengan keadaan tersebut akan lahir konsesus-konsesus minimum bersama yang mengatur kehidupan bersama yang bebas dan rukun. ${ }^{11}$ Toleransi antar umat kemudian menjadi berkembang. Sehingga, kerukunan akan tercipta dengan sendirinya.

Peran pemerintah di dalam keadaan yang demikian sesungguhnya muncul dengan sendirinya, tidak terlalu signifikan dalam kehidupan antar umat beragama. Pentingnya adalah bahwa pengakuan terhadap kebebasan beragama di dalam konstitusi, berfungsi ganda: mengakui bahwa ada agama dan keyakinan, serta mengakui bahwa pemerintah wajib memberikan perlindungan atasnya. Kebebasan adalah sebuah pengakuan terhadap eksistensi manusia, yakni hak asasi. Prinsip utama dari keberadaan hak asasi adalah kebebasan itu sendiri. Perkembangan kehidupan manusia faktanya dimulai dari adanya peningkatan kualitas pengakuan terhadap hak-hak asasi manusia.

\section{RUU KUB sebagai Upaya Justifikasi Majemuk}

Justifikasi majemuk merupakan inti utama dalam upaya regulasi di dalam RUU KUB. Bahwa masalah kebebasan beragama sangat tepat untuk menggambarkan solidaritas universal

\footnotetext{
10 Weinata Sairin, Victor Imanuel Tanja, dan Eka Darmaputera, 'Berbagai Dimensi Kerukunan Umat Beragama' dalam Weinata Saurin, Kerukunan Umat Beragama Pilar Utama Kerukunan Berbangsa: Butir-butir Pemikiran (Gunung Mulia 2006) 28.

11 Ibid. 29-30.
} 
terhadap pengakuan dan penghormatan terhadap orang atau individu yang berpegang teguh pada doktrin (baca; iman) yang secara keseluruhan berbeda dan tidak berkaitan satu sama lain. Permasalahannya kemudian memuncak pada bagaimana memberikan justifikasi majemuk atas hak asasi manusia yakni kebebasan beragama atau berkeyakinan di dalam anggota masyarakat yang saling bersaing dan/atau saling toleran.

Sekadar pengakuan di dalam tatanan norma (apalagi norma tertulis) belumlah cukup. Komunitas masyarakat yang menganut agama yang berbeda-beda, memiliki komitmen terhadap pandangan hidup berlandasan agama masing-masing. Kecenderungan untuk menjadi fanatik kemudian menerapkannya dalam kehidupan sehari-hari, menggairahkan penyebaran nilai dan paham-paham. Oleh karena itu, (rencana) menjustifikasi majemuk melalui RUU KUB, diragukan apakah kemudian dapat menyediakan ruang akomodasi bagi perdamaian di dalam masyarakat, yang di dalam RUU KUB disebut dengan kerukunan, sebagai fundamental approach bagi lembaga dan kestabilan kehidupan sosial.

Di kehidupan nyata, RUU KUB akan diuji apakah yang diaturnya menjadi rangsangan bagi masyarakat untuk toleran atau bahkan digunakan sebagai alat untuk mengintervensi keberadaan umat beragama di Indonesia. RUU KUB bisa saja melegalisasikan kehidupan beragama yang nyaman, namun juga melegalisasikan usaha-usaha untuk membatasi ruang gerak penyebaran agama melalui eksistensi umat, khususnya kaum minoritas. Pada tingkatan lokal misalnya sudah terjadi beberapa hal yang merupakan pelanggaran atas kebebasan beragama, yang sebagaimana dilaporkan oleh ELSA bahwa di Jawa Tengah Hasilnya, ada 20 kejadian yang diduga mengandung unsur pelanggaran dalam bentuk komisi (tindakan langsung) ataupun omisi (pembiaran). Beberapa hal yang terindikasi mengandung unsur pelanggaran antara lain terjadi pada kasus perizinan Gereja Injili di Tanah Jawa (GITJ) Dermolo, Kabupaten Jepara, Vonis 4 tahun untuk pimpinan Amanat Keagungan Ilahi (AKI) di Klaten, Problem pendidikan Agama bagi komunitas Sedulur Sikep di Kudus, Intimidasi dan Penolakan pembangunan Mesjid Jemaat Ahmadiyah di Kendal, Usulan draft Perda Baca Tulis Al-Qur'an di Wonogiri, Kasus salah tangkap terduga teroris di Solo, pemberhentian kegiatan Yatain (Yayasan Tauhid Indonesia) di Sukoharjo dan Karanganyar serta kasus-kasus lainnya. ${ }^{12}$

Keadaan yang demikian kemudian oleh RUU KUB hendak digambarkan bagaimana antisipasi dan solusi yang dapat diambil. Sebagaimana disampaikan W. Cole Durham Jr., yang menyatakan bahwa kemerdekaan beragama dan berkeyakinan membutuhkan beberapa prasyarat di

12 Tedi Kholiludin dkk., Laporan Tahunan Kebebasan Beragama dan Berkeyakinan di Jawa Tengah Tahun 2012 (Lembaga Studi Sosial dan Agama/eLSA 2013). 
antaranya: (1) pengakuan dan penghormatan atas pluralisme; (2) stabilitas ekonomi; (3) pemerintahan dengan legitimasi yang kuat; (4) kelompok-kelompok masyarakat mempunyai cara pandang yang positif atas perbedaan satu sama lain. ${ }^{13}$ Inikah kemudian perilaku masyarakat yang hendak diarahkan atau dirubah atau dikoreksi oleh peraturan perundangundangan tentang kerukunan umat beragama di Indonesia nantinya?

Akhirnya kembali kepada para stakeholders yang memiliki perannya masing-masing dalam memandang peraturan perundang-undangan tersebut nanti-nya. Menjaga agar tidak muncul krisis tanggung jawab, menciptakan kesadaran yang berkelanjutan, serta mencegah penafsiran yang berlebihan, diharapkan menjadi kunci dalam penerapan regulasi. Di samping itu, RUU KUB dimimpikan untuk tidak menjadi belenggu baru nantinya terhadap kalangan umat dan keyakinan minoritas. Reformasi hukum memang perlu, tapi mereformasi pemikiran agar memiliki kesadaran untuk menghargai perbedaan lebih diutamakan.

Bertolak dari pemikiran di atas, pluralism yang lahir dari kebebasan beragama yang dijamin oleh konstitusi, berubah menjadi isu negatif dalam keberadaan RUU KUB, yang hal ini perlu untuk segera diluruskan. Pluralisme adalah karakteristik yang dimiliki bangsa Indonesia. Dan kerukunan merupakan nilai-nilai yang telah dimiliki oleh bangsa Indonesia sejak jaman dulu dan merupakan sesuatu yang bersifat dinamik. Kerukunan tidak terutama dihasilkan dari aturan yang bersifat eksternal, yakni melalui peraturan perundang-undangan, namun secara otentik tumbuh dari dalam penghayatan iman masing-masing individu dan melalui dinamika perjumpaan antar umat yang berbeda. Dengan keadaan tersebut akan lahir konsesus-konsesus minimum bersama yang mengatur kehidupan bersama yang bebas dan rukun. ${ }^{6}$ Bilamana Undang-undang Kerukunan Umat Beragama ini diundangkan sudah sepantasnya mengamanatkan dan mendorong kerukunan tersebut terjadi bukan sekedar mengatur seperti yang terdapat dalam draft RUU KUB tersebut di atas. Toleransi antar umat kemudian menjadi berkembang sebagai perwujudan dari Kebhinneka Tunggal Ika-an bangsa Indonesia. Sehingga, kerukunan akan tercipta dengan sendirinya. Semoga.

\section{DAFTAR BACAAN}

Elza Peldi Taher, Merayakan Kebebasan Beragama: Bunga Rampai Menyambut 70 Tahun Johar Effendi. ICRP bekerja sama dengan KOMPAS; Jakarta, 2009 
Kebebasan Beragama atau

Berkeyakinan: Seberapa Jauh?

Kanisius; Jakarta, 2010

Tedi Kholiludin, dkk. Laporan Tahunan

Kebebasan Beragama dan Berkeyakinan Di Jawa Tengah Tahun 2012. Lembaga Studi Sosial dan Agama (eLSA) Semarang, 2013.

Weinata Sairin, Victor Imanuel Tanja, dan Eka Darmaputera. Berbagai Dimensi Kerukunan Umat Beragama (artikel) dimuat di dalam Kerukunan Umat Beragama Pilar Utama Kerukunan Berbangsa: Butir-butir Pemikiran. Penyunting Weinata Saurin. Gunung Mulia; Jakarta, 2006.

http://www.setara-institute.org/en/ content/ruu-kub-segregatif-danmengikis-jaminan-konstitusionalwarga-negara

Ikhlas BERAMAL, Nomor 62 Tahun XIII April 2010. 